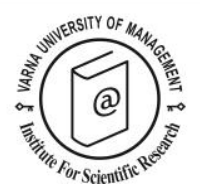

\title{
Biosecurity Risk and Tourist Communication in Ireland
}

\author{
James Hanrahan ${ }^{1}$ and Domhnall Melly ${ }^{2 *}$
}

Received: 05/07/2018 Accepted: 14/11/2018

\footnotetext{
1 School of Business and Social Sciences, Department of Marketing, Tourism and Sport, Institute of Technology Sligo, Ireland

2 School of Business and Social Sciences, Department of Marketing, Tourism and Sport, Institute of Technology Sligo, Ash Lane, Sligo, Ireland; phone: +353 874137535; e-mail: Domhnall.melly@mail.itsligo.ie

* Corresponding author
}

Coordinating editor: Stanislav Ivanov

\begin{abstract}
A lack of sufficient biosecurity communication for tourists can lead to higher biosecurity risk which may result in severe environmental, human health and associated economic impacts. The scope of this research is to assess biosecurity plans and communication strategies of Ireland's major ports, state agencies and governing bodies involved in outdoor recreational activities which have the potential to mitigate biosecurity risk. A mixed method approach was utilised which consisted of content analysis as well as structured qualitative interviews. Analysis has revealed limited communication to tourists arriving in Ireland's ports and few plans or biosecurity communication strategies in place by national agencies. The need to provide adequate communication of biosecurity measures aimed at mitigating the potential for tourists to vector dangerous microbes and aid biological invasions seems not to have been recognised. In order to reduce Ireland's biosecurity risk the need for comprehensive biosecurity planning and communication is vital in order to increase tourist awareness of biosecurity measures at pre-border, border, and post-border stages. This paper concludes that low levels of biosecurity communication is worrying and may pose a considerable biosecurity risk to Ireland. It offers an opportunity to be improved before a serious biosecurity breach occurs possibly resulting in a lost tourist season or expensive eradication programmes as has been witnessed in other destinations worldwide. This research has also highlighted the need for theory to adequately reflect the role of communication by emphasising its inclusion in new or updated biosecurity frameworks to be developed into the future.
\end{abstract}

Keywords: Biosecurity, Tourism, Communication, Strategy, Plan, Ireland.

Citation: Hanrahan, J., D. Melly (2019) Biosecurity Risk and Tourist Communication in Ireland. European Journal of Tourism Research 22, pp. 45-61

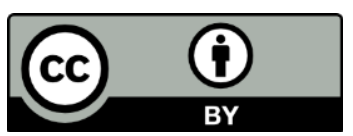

RESEARCH PAPER
This work is licensed under the Creative Commons Attribution 4.0 International (CC BY 4.0). To view a copy of this license, visit https://creativecommons.org/licenses/by/4.0/ 
Biosecurity Risk and Tourist Communication in Ireland.

\section{Introduction}

\section{Rationale}

The rationale for this paper is centred around the dearth of academic research on biosecurity risk and tourist communication in Ireland. Biosecurity research in Ireland focuses on the agriculture industry (O'Connor et al. 2012; Sayers et al. 2013) and tourists who constitute a major vector receive little mention. The tourism industry is a significant contributor to the Irish economy and represents $10.4 \%$ of the country's total GDP (WTTC, 2018). However, tourism is also known to generate negative impacts by potentially contributing to an increased level of biosecurity risk to both human health and the environment. The justifications for this research is the pivotal role implementing biosecurity commination can have on the effectiveness of biosecurity measures (Gunn et al., 2008; Palmer et al., 2009; Nöremark et al., 2016). This is most notably the case with tourism that is considered a major pathway for the spread of invasive alien species (Anderson et al. 2015) and infectious disease (Baker, 2015). The communication of biosecurity measures to tourists in Ireland is of critical importance.

Major biosecurity events have been witnessed as far back as 165BC. However, of notable significance was the 1347 bubonic plague that caused the death of over a third of Europe's populations (Frith, 2012). The primary pathway for such diseases has been observed to be human vectors aboard ships (Hayes, 2005). In more recent times, modern day tourism sees the world becoming increasingly mobile and interconnected. This can be characterised by freedom of movement and drastically reduced journey times. All of these factors can contribute to an increased risk of human-tohuman transmission of infectious diseases (Beigel et al. 2005). With international tourist arrivals worldwide increasing $7 \%$ in 2017 to reach 1,322 billion (UNWTO, 2018), tourism is a significant element of this growth in population mobility. Therefore, governments may need to place greater emphasis on biosecurity and more specifically biosecurity communication to tourists.

International literature clearly indicates the strong link between tourism and biosecurity.
Tourists can easily carry person-to-person transmitted infections to any part of the world (Baker, 2015). Increasing tourist mobility has become a major factor in the current and emerging patterns of disease (Hall, 2006). Another element of biosecurity is communication and the potential for 'bad news' arising from disease outbreak resulting in lost tourism revenues (Hall, 2011). Powell \& Leiss, (1997) supported this by stating that poor risk communication can result in economic consequences and substantial declines in visitation. However, improved biosecurity communication to tourists could be the most effective way of increasing biosecurity practices (Colmar Brunton, 2013; Anderson et al. 2014a; Baker, 2015).

\section{Aim and objectives}

The primary aim of this paper was to assess the extent of biosecurity communication in place for tourists in Ireland. This was done by analysing all biosecurity plans and communication strategies of Ireland's major ports, state agencies and governing bodies. Specifically, forty-one agencies and state bodies were identified which will need to be incorporated into the conceptual framework. These agencies are key stakeholders for communicating biosecurity measures to tourists. The objective of the study was to determine to what extent these agencies are communicating biosecurity to tourists. All plans, policies, strategies, guidelines and online media of these agencies have been assessed to identify if any biosecurity communication exists. The findings from this paper are discussed and critically assessed in the context of international best practice to potentially reduce biosecurity risk in Ireland.

\section{Literature review}

\section{Tourism and biosecurity}

Increases in global tourism and migration have led to an increased level of biosecurity risk around the globe (Gushulak \& MacPherson 2004; Pickering et al. 2007; Pyšek \& Richardson, 2010; Hall, 2011; Anderson et al. 2015; Layton et al. 2017). Instances of biological invasions are increasing around the world, resulting in high control and eradication costs. Furthermore, major outbreaks around the world are gathering increasing attention 
due to their devastating toll to human health. One of the most significant contributors to biosecurity risk is the extent to which tourists can vector pests or diseases. Increasing spatial movements of international tourists has resulted in the spread of infectious diseases globally (Baker, 2015). Furthermore, outdoor recreational tourism activities are a major pathway for the spread of invasive alien species (Anderson et al. 2015).

Major incidents emphasise the importance of governments establishing and enforcing biosecurity. The 2003 outbreak of Severe Acute Respiratory Syndrome (SARS) in Hong Kong resulted in over 770 human fatalities (McAleer et al. 2010). This outbreak cost China's tourism industry $€ 15$ billion (HKTDC, 2003). Furthermore, Wilder-Smith et al. (2003) highlights how tourist airline travel significantly contributed to the spread of serious SARS throughout the globe.

Although tourism is considered to be the centrepiece for biosecurity measures, there is little discussion on the importance of such measures in tourism literature. This may be due to the industry being unprepared for the implications that biosecurity breaches have on the tourism industry. For example, the Irish National Biodiversity Action Plan 2017 and the Invasive Alien Species Strategy for Northern Ireland have very little mention of tourism. This is despite tourism potentially having a considerable impact on the development and implementation of biosecurity measures. Three decisive stages of biosecurity implementation represent three critical stages of a tourist's journey occurring at pre-border, border, and post-border (Biosecurity Strategy Development Team, 2001a, b; Hall, 2005). In addition, a wider diffusion of potential biosecurity threats is occurring due to tourists using smaller hub airports (Gaber et al. 2009). From an environmental perspective, increasing numbers of tourists are participating in common outdoor recreational activities such as hiking, and mountain biking (Tverijonaite et al. 2018). These activities can act as forms of habitat disturbance, potentially facilitating species invasion (Pickering et al. 2007; Pickering et al. 2010; Tobin et al. 2010; Jauni et al. 2014).
The costs of biosecurity breaches associated with both invasive alien species' and infectious diseases are substantial. In Europe alone, it is estimated that more than ten thousand nonnative species have become invasive, costing $€ 12 b n$ per year (EEA, 2012). Rassy and Smith (2013) underline how Mexico lost an entire tourist season and incurred losses of around $€ 2$.2bn due to the Swine Flu pandemic in 2009.

In order to mitigate the risk of infectious diseases and invasive alien species entering a country, many governments have introduced biosecurity strategies. This is seen in countries such as New Zealand and Australia who have been at the forefront of tourism biosecurity. The development of strategies such as 'Biosecurity 2025' highlights tourism as a key industry regarding the implementation of biosecurity measures. This may be due to the serious environmental damage and economic costs resulting from the highly invasive algae Didymosphenia Geminata (Didymo). Evidently, New Zealand has had a biosecurity strategy in place since 2003. European countries however have been much slower to adopt biosecurity strategies. This is despite free movements for citizens within the Schengen and common travel area. Over a decade later, the European Commission adopted a regulation "on the prevention and management of the introduction and spread of invasive alien species" (EU Regulation 1143/2014). In contrast to New Zealand, EU Regulation 1143/2014 only came into force in 2015 (Bazzichetto, 2018). This regulation identifies research, monitoring and surveillance for early detection of invasive alien species. Tourists could potentially play an important role in these processes due to their potential to the spread of invasive alien species. The implementation of biosecurity measures at pathways of initial introduction (Hulme et al. 2008) is suggested by Anderson et al. (2015) as the most effective mitigation process. This process can also promote monitoring, surveillance and early detection resulting in effective risk mitigation. Anderson's biosecurity measures will need to be incorporated into the conceptual framework for this study. The communication of key processes for monitoring, mitigation and eradication are crucial in alleviating the risk of biosecurity breaches on a destination. 
Biosecurity and tourism in Ireland

Ireland has witnessed the severe impacts of a reactive biosecurity system, most notably the 2001 foot and mouth (FMD) outbreak (O'Reilly et al. 2003). The initial introduction of FMD to Ireland occurred unnoticed due to a lack of biosecurity surveillance. This resulted in countrywide dispersal of the disease through unregulated livestock movements. Significantly, biosecurity measures only preceded the outbreak. These measures consisted of intensive disinfection procedures that were initiated nationally at entry to farms, schools, and other public buildings. This outbreak resulted in a mass animal culling operation commencing of cattle, pigs, and goats, including over 13,000 sheep. The resulting impacts to government expenditure was over $€ 100 \mathrm{~m}$ while the estimated negative impact on tourism revenues was $€ 200 \mathrm{~m}$ (O'Toole, et al. 2002).

In more recent times, biosecurity concerns are of increasing significance to the Island of Ireland and its tourism industry. Ireland's natural environment and unspoilt surroundings are key to many of Tourism Ireland (who promotes the entire Island of Ireland as a tourism destination) marketing campaigns. Overseas tourist visits to the island of Ireland in 2016 increased by $7.7 \%$ to 10.3 million compared to 2015 (Tourism Ireland, 2015; 2016). However, the consequential costs associated with biosecurity breaches can have a significant impact on tourism revenue. Significantly, there are currently 128 invasive alien species established in Ireland, 51 of which are classed as 'high impact' species, representing a substantial risk to Ireland's environment and tourism industry (National Biodiversity Data Centre, 2018). The estimated costs of invasive alien species to tourism and recreation in Ireland are substantial. The current estimated annual cost of invasive and non-native species to Ireland and Northern Ireland reached $€ 261$ million (Kelly et al. 2013). In order to combat this, Inland Fisheries Ireland has developed biosecurity guidelines for specific high risk recreational activities. These guidelines aim to the halt the vectoring of invasive alien species and diseases from anglers, boaters, paddle sports, and scuba diving. Such guidelines can effectively target the pathways of introduction such as hull fouling as identified by Hulme et al. (2008). However, these guidelines fail to incorporate sufficient communication to tourists. In contrast, the UK implements a specific invasive alien species communication plan. This communication plan targets all recreational water users (freshwater), including anglers, boat and kayak users, and exotic pet owners (MCWG, 2017). A specifically designed biosecurity communication strategy is a significant step in acknowledging the importance communicating biosecurity and should be implemented in Ireland.

\section{Biosecurity and tourist communication}

According to the WHO (2010), a system for communication and information exchange are key for a harmonized and integrated approach to biosecurity. Furthermore, advances in communications and global access to biosecurity information are key influencing factors for biosecurity (WHO, 2010). The importance of effective biosecurity communication can be seen from the 2009 Swine flu outbreak in Mexico. Swine flu sparked a rapid increase in global communication activities by governments, journalists, and more importantly; citizens themselves (Findlater \& Bogoch, 2018). The rapidly evolving nature of technological innovations allowed information to travel from unofficial sources on social media platforms (Nerlich \& Koteyko, 2012). This can potentially prompt fear and anxiety that most certainly alter tourists travel choices and behaviours (Birnbrauer, Pennington-Gray, \& Donohoe, 2013; Donohoe, Pennington-Gray, Omodior, 2015).

A lack of clear top down biosecurity communication can bring about severe negative economic impacts (Rassy and Smith, 2013). This problem may be related to the understanding that individuals use media coverage as a cognitive shortcut to make sense of complex issues (Jen-Shih et al. 2008). Significantly, media coverage tends to focus predominantly on specific instances of hazardous situations, short-term consequences and hazardous themes (Jen-Shih et al. 2008). Leung et al. (2013) discusses the important role of social media in both tourists' decision 
making. Technological advances in communication for instance social media can allow people to become the media themselves for sharing information (Thevenot, 2007; Li \& Wang, 2011). However, official communication from experts about a pandemic may have to compete with a plethora of new modes of lay communication (Nerlich \& Koteyko, 2012). The presence of a communication strategy could alleviate tourist's risk perception that could interfere with their travel decisions.

A significant concern is the ability of a tourist with an infectious disease to travel to any part of the world within 24 hours (Baker, 2015). Increasing numbers of tourists crossing international borders (UNWTO, 2018) are considered to be driving forces for the spread of infectious diseases worldwide. These tourists can vector infectious disease and have the potential to infect non travellers in their new destination (Hass et al. 2003). This draws attention to issue of tourists themselves acting as a host for infectious disease, further emphasising the importance of biosecurity awareness.

Communication from experts and authorities may be crucial for reducing potential pathways of introduction (Anderson et al. 2015). The pathways of initial introduction framework (Figure 1) provided by Hulme et al. (2008) segregates the different processes which make up the specific pathway. Specifically, hull

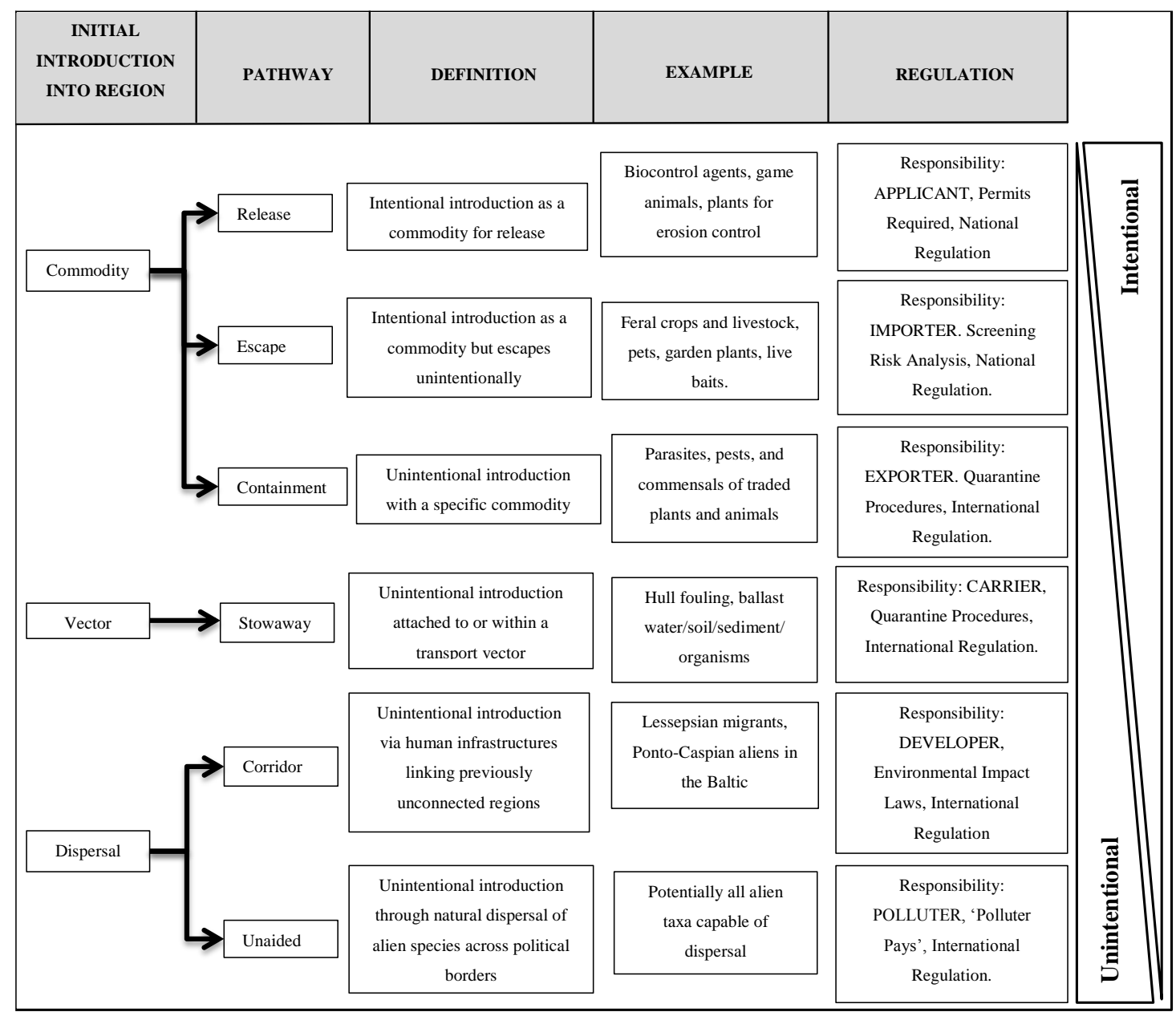

Figure 1. Pathways of initial introduction framework Source: Adapted from Hulme et al. (2008) 
fouling is mentioned as it provides a vector for stowaways concealed on the hulls of boats. The development of such a framework may be a critical proactive process for identifying and informing unknowing vectors of adequate biosecurity measures (Pickering et al. 2007). Hulme et al. (2008) identifies an abundance of potential vectors and pathways for biosecurity threats (Figure 1). Implementing national governance alone may not be sufficient to mitigate the risk of biological invasions. The need for regulations, laws and a concise management plan for invasive alien species are required with a focus on tourist activities and communication (Pickering et al. 2007; Hall, 2011; Anderson et al. 2015). Furthermore, international health regulations, EU regulations and Laws have been developed to support countries in combating biosecurity risk. These will need to be incorporated within the conceptual framework for biosecurity risk and tourist communication.

This pathways of initial introduction framework (figure 1) addresses the need for identifying pathways for biosecurity threats. Clearly this framework could benefit with an element of communication. Future frameworks could prevent tourist vectoring from an uptake in best practice guidelines by including biosecurity communication. Clear, transparent, and effective tourist communication can be an essential tool in mitigating biosecurity risk in a destination. This will need to be incorporated into the conceptual framework for this study.

Biosecurity communication at an individual level for tourists could be considered as ultimately the most important stage of biosecurity. This may be due to tourists themselves providing the pathway for introduction. A significant educational tool for informing tourists is the use of customs and passenger declarations (Hall, 2005). This can also be a means of gathering traveller information and alert customs officials to potential biosecurity risks. Of potential interest to tourism agencies are questions as to whether passengers have partaken in high risk recreational activities. Recreational boaters can inadvertently transport harmful invasive alien species from previously visited lakes (Schneider et al. 1998; Johnson et al. 2001;
Rothlisberger et al. 2010; De Ventura et al. 2016). According to the U.S. Fish and Wildlife Service (2015), the more cost efficient and effective biosecurity information dissemination to recreational water users consist of signs at boat ramps. This form of communication is seen in Ireland to prevent the Asian Clam from the river barrow (IFI, 2015). However, more needs to be done to improve tourist awareness. Readily available biosecurity best practice guidelines should be provided to boaters on methods to clean and dry their equipment (Cole et al. 2018).

Communicating a strong biosecurity message to water users at international borders is understood to produce effective biosecurity conformity among tourists (Anderson et al. 2014b). Equally, Ireland could potentially benefit from such an approach due to the large volume of recreational water users. Furthermore, the Invasive Non-native Species Media and Communications Plan for Great Britain has extended its dissemination of biosecurity information posters to airports. This approach has resulted in a significant 9\% increase in people carrying out the good biosecurity practices since its implementation (MCWG, 2017). It is clear that providing tourists with effective biosecurity communication at Ireland's major ports could considerably reduce the country's biosecurity risk.

The conceptual framework (figure 2) frames the assessment of biosecurity communication for tourists in Ireland. This framework is composed of international and European regulation (EU) $1143 / 2014$ on invasive alien species and (EU) $1082 / 2013$ on serious cross border threats to health. These regulations can guide Irish state bodies in developing biosecurity plans and strategies. Communication plays an important role in successfully implementing biosecurity measures (Colmar Brunton, 2013; Anderson et al. 2014a; Baker, 2015). Furthermore, communication forms a crucial element of the conceptual process for this research as it provides a critical link between state bodies and tourists. Communication also underpins many pivotal biosecurity processes such as monitoring, mitigation, and eradication. These processes can be accomplished through a biosecurity strategy and may result in the mitigation of negative destination impacts. 
The conceptual framework (figure 2) supports and informs the research as it identifies the key factors and variables to be studied and the relationship between them (Miles and Huberman, 1994). It provides a clear structure for assessing biosecurity communication in Ireland as it identifies the hierarchal structure for biosecurity implementation. It also determines national agencies and state bodies in a preferable position to implement biosecurity measures to tourists as set out by international and European regulations. Through this conceptual framework, it was deemed appropriate to assess biosecurity risk in Ireland through the level of communication. This was achieved by assessing biosecurity plans and communication strategies within national agencies and state bodies.

\section{Methodology}

In order to undertake an assessment of biosecurity communication for tourists in Ireland, this study employed a mixed method approach. Initially a theoretical framework was developed which informed the construction of a detailed content analysis tool. This was utilised in tandem with structured qualitative interviews. The use of content analysis according to Berelson (1952:18) "allows for the objective, systematic and quantitative description of the manifest content of communication". Content analysis allowed for an assessment of biosecurity communication from key and national agencies, and points of entry in Ireland. Through an in-depth review of theory, in addition to assessing international examples, the researcher identified forty-one national and key agencies and points of entry in Ireland as listed in table 1. This informed the development of the conceptual framework in figure 2 . Through empirical findings identified in international literature, the researchers understood that the selected sample would be in a favourable position to increase implementation of biosecurity measures for tourists in Ireland through an effective biosecurity communication strategy or plan.

The criteria to be analysed focused on the presence of: a biosecurity plan, a biosecurity plan comprising of any elements of communication, and biosecurity communication strategy. This research was conducted by analysing the official plans, policies, strategies, and media of specific national and key agencies, as well as points of entry in Ireland in relation to tourism. In addition to a comprehensive content analysis, qualitative

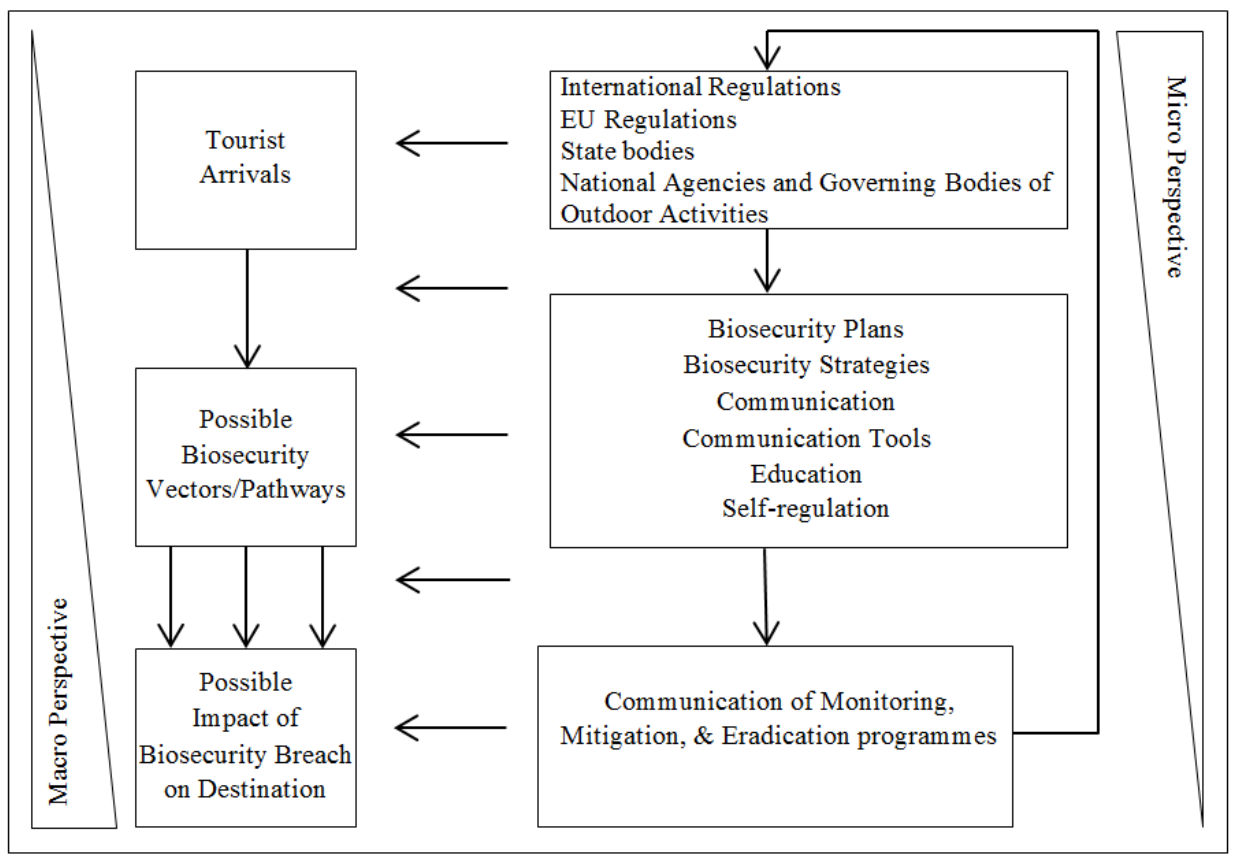

Figure 2: Conceptual framework for assessing biosecurity communication for tourists in Ireland 
data within this study was attained by conducting structured qualitative interview with personnel responsible for biosecurity within the agencies. The data gathered was analysed with qualitative software analysis Nvivo. The data was gathered in February and April of 2018 and was inputted into a tourism biosecurity matrix tool which was specifically designed from the theoretical framework and included specific criteria to be assessed. The results have been analysed and discussed with reference to international standards of biosecurity best practice. The findings established in this study will grant a basis for further research of tourists acting as vectors of biosecurity threats in Ireland which will be facilitated through grounded theory.

\section{Results}

Irelands biosecurity communication overview

This research provides a snapshot of biosecurity risk and tourist communication in
Ireland. The analysis revealed that $95 \%$ of agencies in Ireland do not have a biosecurity plan and $97 \%$ do not have a biosecurity communication strategy in place. This low level of planning and communication is significant given the importance of integrating clear tourist communication needed to mitigate biosecurity risk. The significance of having adequate biosecurity communication for tourists in Ireland cannot be underestimated given the $5.7 \%$ growth of international tourists visiting Ireland (Fáilte Ireland, 2018). Furthermore, the importance of tourist communication is emphasised within the Great Britain Invasive Non-native Species Strategy as well as international literature (Smith, 2006; Anderson et al. 2014a; Cole et al. 2018). However, out of the forty-one agencies assessed, only one, the Health Service Executive (HSE) was found to have a biosecurity communication strategy in place. Further assessment also revealed that Inland Fisheries Ireland have a biosecurity plan

Table 1. Sample used for assessing biosecurity communication for tourists

\begin{tabular}{|c|c|c|c|}
\hline $\begin{array}{c}\text { National Agency/Key } \\
\text { Agency /Points of Entry }\end{array}$ & $\begin{array}{c}\text { Relevant Plans, Policies, } \\
\text { Strategies, and Media Included } \\
\text { for Content Analysis }\end{array}$ & $\begin{array}{l}\text { National Agency/Key } \\
\text { Agency /Points of Entry }\end{array}$ & $\begin{array}{c}\text { Relevant Plans, Policies, } \\
\text { Strategies, and Media } \\
\text { Included for Content Analysis }\end{array}$ \\
\hline Angling Council of Ireland & www.anglingcouncil.ie & $\begin{array}{l}\text { Irish Disabled Sailing } \\
\text { Association/Sailforce }\end{array}$ & $\begin{array}{l}\text { www.afloat.ie/resources/organis } \\
\text { ations/irish-disabled-sailing- } \\
\text { association }\end{array}$ \\
\hline Angling Ireland & www.fishinginireland.info & Irish Ladies Golf Union & www.golfnet.ie \\
\hline Ballooning Ireland & www.ballooningireland.ie & $\begin{array}{l}\text { Irish Marina Operators } \\
\text { Association }\end{array}$ & $\begin{array}{l}\text { www.afloat.ie/resources/organis } \\
\text { ations/irish-marina- } \\
\text { operatorsassociation }\end{array}$ \\
\hline Bird watch Ireland & www.birdwatchireland.ie & Irish Marine Federation & www.irishmarinefederation.com \\
\hline Canoeing Ireland & www.canoe.ie & $\begin{array}{l}\text { Irish Mountain Running } \\
\text { Association }\end{array}$ & www.imra.ie \\
\hline $\begin{array}{l}\text { Cruising Association of } \\
\text { Ireland }\end{array}$ & www.cruisinginireland.com & $\begin{array}{l}\text { Irish Orienteering } \\
\text { Association }\end{array}$ & www.orienteering.ie \\
\hline Cycling Ireland & www.cyclingireland.ie & Irish Sailing Association & www.sailing.ie \\
\hline Donegal Airport & www.donegalairport.ie & $\begin{array}{l}\text { Irish Sea Kayaking } \\
\text { Association }\end{array}$ & www.iska.ie \\
\hline $\begin{array}{l}\text { Dublin Airport Authority } \\
\text { Dublin Port } \\
\text { Fáilte Ireland }\end{array}$ & $\begin{array}{l}\text { www.daa.ie } \\
\text { www.dublinport.ie } \\
\text { www.Fáilte Ireland.ie }\end{array}$ & $\begin{array}{l}\text { Irish Surfing Association } \\
\text { Irish Trails } \\
\text { Irish Underwater Council }\end{array}$ & $\begin{array}{l}\text { www.irishsurfing.ie } \\
\text { www.irishtrails.ie } \\
\text { www.diving.ie }\end{array}$ \\
\hline Golfing Union of Ireland & www.golfnet.ie & $\begin{array}{l}\text { Irish Waterski and } \\
\text { Wakeboard Federation }\end{array}$ & www.irishwwf.ie \\
\hline $\begin{array}{l}\text { Heritage Boat Association } \\
\text { Horse Sport Ireland }\end{array}$ & $\begin{array}{l}\text { www.heritageboatassociation.ie } \\
\text { www.horsesportireland.ie }\end{array}$ & Killybegs Harbour & $\begin{array}{l}\text { www.killybegsharbour.ie } \\
\text { www.mountaineering.ie }\end{array}$ \\
\hline HSE & www.hse.ie/eng & $\begin{array}{l}\text { National Coarse Fishing } \\
\text { Federation }\end{array}$ & www.ncffi.ie \\
\hline Inland Fisheries Ireland & www.fisheriesireland.ie & Outdoor Education Ireland & www.oei.ie \\
\hline $\begin{array}{l}\text { Inland Waterways } \\
\text { Association of Ireland }\end{array}$ & www.iwai.ie & Rowing Ireland & www.rowingireland.ie \\
\hline $\begin{array}{l}\text { Ireland's Association for } \\
\text { Adventure Tourism }\end{array}$ & www.iaat.ie & Scout Ireland & www.scouts.ie \\
\hline Ireland West Airport & www.irelandwestairport.com & $\begin{array}{l}\text { Speleological Union of } \\
\text { Ireland }\end{array}$ & www.caving.ie \\
\hline $\begin{array}{l}\text { Irish Camping and } \\
\text { Caravan Club } \\
\text { Irish Cruiser Racer } \\
\text { Association } \\
\end{array}$ & $\begin{array}{l}\text { www.iccc.ie } \\
\text { www.afloat.ie/sail/icra }\end{array}$ & Triathlon Ireland & www.triathlonireland.com \\
\hline
\end{tabular}


however, there was only minor elements of communication found within this. The only other agency found to have a biosecurity plan was Bird Watch Ireland, yet this plan did not mention any elements of communication.

\section{Results for human health concerns.}

The only biosecurity communication strategy in Ireland is located within the National Pandemic Influenza Plan for Ireland and developed by the HSE. Its compulsory development is based on instruction from the World Health Organisation (WHO, 2005). Crucial methods of communication for an influenza pandemic are outlined. Processes of communication consist of a leaflet drop, regularly updated website, press briefings, and television and radio updates. It appears essential that communicating advice and guidance often stands as the most important public health tool in managing a risk (WHO, 2008). Evidently the sharing of this advice is considered of high importance as it could potentially reduce the risk of tourists vectoring infectious diseases. According to the (WHO, 2009:29) "The goal of communications before and during a pandemic is to provide and exchange relevant information with the public, partners, and stakeholders to allow them to make well informed decisions and take appropriate actions to protect health \& safety, and response of which communication is a fundamental part of". Therefore, this communication strategy can play a crucial role in protecting human health and Ireland's tourism industry by improving tourist awareness of infectious disease outbreaks.

\section{Results for environmental concerns}

Further assessment of agencies revealed that only $5 \%$ had a biosecurity plan, while only $3 \%$ had a plan with any elements of communication. Although it is acknowledged the presence of communication within such plans or strategies is a positive finding, these could do much more to provide clear biosecurity communication to tourists in Ireland. For instance, the only plan with communication for environmental biosecurity concerns was the After Life Communication Plan that was developed as part of the CAISIE project (Control of Aquatic Invasive Species and Restoration of Natural Communities in Ireland). This was set up by the state agency Inland
Fisheries Ireland in order to minimise the threat from invasive alien species. Crucially, the aim for tourist communication in this plan are to "create awareness of invasive species at all levels and to promote and implement biosecurity measures" (IFI, 2013:2). However, this plan only focuses on the high risk areas of Lough Corrib and the Grand Canal and Barrow Navigation. A comprehensive integrated political and agency approach covering the entire island of Ireland is required for biosecurity. Furthermore, important pathway management measures outlined in this plan that reflect the need for communication within the initial pathways of introduction framework (figure 1). However, this plan could do much more to inform tourists in other locations and increase its coverage extensively throughout Ireland.

\section{Evaluation of results}

Only $3 \%$ of overall agencies assessed in Ireland had a biosecurity communication strategy in place. This is despite the need for biosecurity communication for tourists in order to mitigate Ireland's biosecurity risk. Significantly, none of the national agencies for the environment had a biosecurity communication strategy developed. This is despite these agencies potential to connect with tourists for issues of monitoring, mitigation, and eradication of invasive alien species. Additionally, biosecurity communication may reduce impacts on a destination from both a micro and micro perspective as shown from the conceptual framework (figure 2). This lack of a communication strategy appeared to be a frequent theme within the smaller national agencies and governing bodies in Ireland. For example, when a national agency was asked if they had a biosecurity communication strategy in place, they responded:

"no, no official strategy but we have had articles in our magazine but it is not part of our formal policy or anything like that." (NGO).

This further highlights an apparent shortfall in communication processes for tourists as there is little dissemination processes in place from national agencies and governing bodies. The lack of a communication strategy is also apparent from many of the key agencies and 
points of entry into Ireland. For example, when a major port was asked about the presence of a biosecurity communication strategy, they responded:

"I wouldn't know anything about that" (Major Port).

This lack of biosecurity knowledge signifies the need for training and education of individuals within these key agencies and points of entry. Furthermore, a biosecurity communication strategy could additionally include provision for personnel training and education through biosecurity workshops and online training modules. This educational element is also included in both the Great Britain Invasive Nonnative Species Strategy and is outlined as a key component for implementing the Invasive Non-Native Species Media and Communications Plan for Great Britain. This approach in Ireland could identify individuals within agencies for training on monitoring, mitigation, and eradication as outlined in Figure 2.

\section{Discussion of findings}

Despite the high level of biosecurity risk in Ireland, the results indicate that national agencies are providing very little biosecurity communication to tourists. Although biosecurity best practice guidelines are outlined within the CAISIE After Life Communication Plan 2013, the national implementation of these vital guidelines are confined to just two specific areas in Ireland. This seems to be a wasted opportunity as the entire island would benefit. As was witnessing in the UK with a $9 \%$ increase in people carrying out the good biosecurity practices since a nationwide communication strategy was implemented (MCWG, 2017). Furthermore, only two national outdoor activity agencies had biosecurity communication in place for visitors or indeed members. These measures have been proven to improve tourist participation in biosecurity best practice guidelines for treating their recreational gear. This is despite substantial growth in nature-based tourism (Davenport et al. 2002; Christ et al. 2003; Pickering et al. 2007; Balmford et al. 2009). However, empirical findings identified in the conceptual framework for assessing biosecurity communication for tourists (figure 2) identified a gap in communication between state bodies and tourists. Communication from national agencies could be used to bridge this gap. Ireland's lack of a clear biosecurity plan for tourism could leave the country vulnerable to increasing biological invasions, high eradication and control costs, and environmental damage from tourists being unaware of biosecurity best practice guidelines.

Regarding human health, the increasing number of international visitors to Ireland results in a heightened risk for tourists vectoring infectious disease. Tourism has been highlighted as a major factor in the global spread of disease, specifically Ebola in 2013 (Baker, 2015) and SARS in 2003 (Moore, 2004). These two incidents highlighted the need for improved biosecurity communication among tourists and significantly resulted in the development of the International health regulations. Outlined in in the conceptual framework (figure 2), these regulations provide Ireland with guidance for infectious disease outbreaks. This can include health service provision for the HSE, and resulted in the development of Irelands only biosecurity communication strategy. However, further emphasis on biosecurity communication was required for this framework, especially within national agencies and major ports. Otherwise the implementation of biosecurity practices may become somewhat too late as an outbreak already may have occurred. The need for a biosecurity communication strategy by agencies at major ports is outlined conceptual framework for assessing biosecurity communication for tourists (figure 2). Major ports such as Dublin Airport and Dun Laoghaire could improve tourist adoption of biosecurity measures through clear communication as they are ideally placed to inform, monitoring and mitigation.

\section{Conclusion}

Contribution

This paper has discussed from both an international and national perspective the relationship between biosecurity risk and tourist communication. Tourism is a significant contributor to biosecurity risk in Ireland. This study contributes to new knowledge regarding the adoption of clear biosecurity 
communication to tourists. Specifically, the focus is on national agencies involving outdoor recreational activities and governance at major ports in Ireland. A lack of awareness and recognition of the effectiveness of biosecurity measures is outlined as a barrier to successful biosecurity implementation (Gunn et al., 2008; Palmer et al., 2009; Nöremark et al., 2016). The conceptual framework for assessing biosecurity communication for tourist (figure 2) has guided this research and helped identify communication from national agencies. It has been established that only $3 \%$ of national agencies have biosecurity communication for tourists in place. This is worrying when the rapid growth of tourists visiting Ireland is considered and the potential impacts to human health and the environment. Therefore, this assessment provides clear direction for future development of essential biosecurity plans and communication strategies from national agencies, state bodies and major ports.

\section{Policy implications}

Two essential policy implications can be drawn from this study. Firstly, tourists engaging in outdoor recreational activities are an increasingly known pathway for the spread of invasive alien species (Pickering et al. 2007; Rothlisberger et al. 2010; Anderson et al. 2015; De Ventura et al. 2016). This has led to several international and European agreements and regulations being developed. Irish biosecurity policy development is guided by international and European regulations which is evident the conceptual framework for assessing biosecurity communication for tourists (Figure 2). However, there is clear a division between the tourists and these regulations due to a lack of communication. Therefore, policy makers should encourage the development of communication strategies at a national level which are aimed at high risk outdoor recreational activities. While some agencies adopt biosecurity guidelines for biosecurity risk mitigation, the communication of these guidelines is lacking. By including communication into biosecurity policy may prevent the severe negative economic impacts from eradication and control measures.

Secondly, increasing volumes of international tourists worldwide has become a major factor in emerging patterns of disease (Hall, 2006; IATA, 2017). Therefore, timely expert communication during an infectious disease outbreak can alleviate tourist vectoring and inaccurate risk perception. This can ensure a destination doesn't inherently go through a lost season due to overreaction of the media. Therefore, policy makers at major ports should develop their own communication strategies in order to alleviate risk perception and provide accurate biosecurity information to tourists and media alike.

\section{Limitations}

This study is not without limitations due to budget and time factors. The focus was centred on the specific conceptual framework. As this assessment focused on national agencies and state bodies, this limited the assessment from analysing tourist behaviours. It would be advantageous to identify the impact biosecurity communication has on tourist's adoption of the limited biosecurity guidelines in Ireland. Tourist behaviour is a decisive factor in uptake of biosecurity best practice guidelines. Several authors have also suggested that biological invasions are still occurring despite biosecurity measures in place (Cole et al. 2016; Kemp et al. 2017). Therefore, other external factors may need to be incorporated in future research in this area.

\section{Future research directions}

This paper is part of a wider doctoral research project and thus facilitates an opportunity for further research. This will allow for a much larger study of tourist vectoring and biosecurity within Ireland. Although this assessment identified minimal biosecurity plans and communications in Ireland, it has established a substantial level of potential risk. This risk needs further assessment in light of the potential negative biosecurity impacts on the economy, human health and environment in Ireland. Outreach research should be conducted to determine what types of communication approaches are most effective (Cole et al. 2018). This study could focus on tourists who have not yet adopted biosecurity measures in order to identify more effective methods of biosecurity communication.

\section{References}

Allen, J.A. Brown, C.S. Stohlgren, T.J. (2008). Non-Native Plant Invasions of United 
States National Parks. Biological Invasions. 11, 2195-2207

Anderson, L.G. Rocliffe, S. Haddaway, N.R. Dunn, A.M. (2015). The Role of Tourism and Recreation in the Spread of NonNative Species: A Systematic Review and Meta-Analysis. PLoS ONE, 10, (10), 1-15

Anderson, L.G. Rocliffe, S. Stebbing, P.D. Dunn, A.M. (2014a). Aquatic Biosecurity Best Practice: Lessons Learned from New Zealand. Defra Science and Research Reports. 1-47.

Anderson, L.G. White, P.C.L. Stebbing, P.D. Stentiford, G.D. Dunn, A.M. (2014b). Biosecurity and Vector Behaviour: Evaluating the Potential Threat Posed by Anglers and Canoeists as Pathways for the Spread of Invasive Non-Native Species and Pathogens. PLOS ONE. 9(4),1-10.

Baker, D. (2015). Tourism and the Health Effects of Infectious Diseases: Are There Potential Risks? International Journal of Safety \& Security in Hospitality \& Tourism, 12(1), 41-59

Balmford, A. Beresford, J. Green, J. Naidoo, R. Walpole, M. Manica, A. (2009). A Global Perspective on Trends in Nature-Based Tourism. PLoS Biology, 7(6), 1-6

Barros, A. Pickering, C.M. (2014). Non-native Plant Invasion in Relation to Tourism Use of Aconcagua Park, Argentina, the Highest Protected Area in the Southern Hemisphere. Mountain Research and Development, 34, 13-26

Bastida, U. Huan, T.C. (2014). Performance Evaluation of Tourism Websites' Information Quality of Four Global Destination Brands: Beijing, Hong Kong, Shanghai, and Taipei. Journal of Business Research, 67(2), 167-170

Bazzichetto, M. Malavasi, M Bartak, V. Acosta, A.T.R. Rocchini, D. Carranza, M.L. (2018). Plant Invasion Risk: A Quest for Invasive Species Distribution Modelling in Managing Protected Areas. Ecological Indicators. 95(1), 311-319

Beigel, J.H. Farrar, J. Han, A.M. Hayden, F.G. Hyer, R. de Jong, M.D. Lochindarat, S. Nguyen, T.K. Nguyen, T.H. Tran, T.H. Nicoll, A. Touch, S. Yuen. K.Y. (2005). Avian Influenza A (H5N1) Infection in
Humans, New England Journal of Medicine, 353, 1374-1385

Berelson, B. (1952). Content Analysis in Communication Research. The Free Press, Glencoe, Illinois.

Beville, S.T. Kerr, G.N. Hughey, K.F. (2012). Valuing Impacts of the Invasive Alga Didymosphenia Geminata on Recreational Angling. Ecological Economics, 82, 1-10

Biosecurity Council. (2003). The Biosecurity Strategy for New Zealand. Tiakina Aotearoa Protect New Zealand August 2003. Retrieved from: https://www.mpi.govt.nz/dmsdocument/13 197-tiakina-aotearoa-protect-new-

zealand-summary/sitemap. Accessed on: 17/10/2018.

Biosecurity Strategy Development Team. (2001a). A Biosecurity Strategy for New Zealand, Strategy Vision Framework Background Paper for Stakeholder Working Groups. Wellington: Biosecurity Strategy Development Team.

Biosecurity Strategy Development Team. (2001b). Developing a Biosecurity Strategy for New Zealand: A Public Consultation Paper. Wellington: Biosecurity Strategy Development Team.

Birnbrauer, K. Pennington-Gray, L. Donohoe, H. (2013). Dengue Fever Knowledge, Attitudes and Practices among Bahamians and U.S. Tourists. British Global and Travel Health Association Journal, 22, 56-60

Briski, E. Wiley, C.J. Bailey, S.A. (2012). Role of Domestic Shipping in the Introduction or Secondary Spread of Nonindigenous Species: Biological Invasions within the Laurentian Great Lakes. Journal of Applied Ecology, 49, 1124-1130

Chan, F.T. Bailey, S.A. Wiley, C.J. Maclsaac, H.J. (2012). Relative Risk Assessment for Ballast-Mediated Invasions at Canadian Arctic Ports. Biological Invasions, 15, (2), 295-308

Christ, C. Hillel, O. Matus, S. Sweeting, J. (2003). Tourism and Biodiversity Mapping Tourism's Global Footprint. Washington, D.C. Conservation International, 1-52

Cole, E. Keller, R. Garbach, K. (2016). Assessing the Success of Invasive Species Prevention Public Outreach and Education Efforts at Changing the Behaviours of Recreational Boaters. 
Journal of Environmental Management. 184, 210-218

Cole, E. Keller, R.P. Garbach, K. (2018). Risk of Invasive Species Spread by Recreational Boaters Remains High Despite Widespread Adoption of Conservation Behaviours. Journal of Environmental Management. 229, 112-119

Colmar Brunton. (2013) Check, Clean, Dry Monitor 2013. Annual Audience Monitoring Report for MPI. Retrieved from: https://www.mpi.govt.nz/dmsdocument/39 77/. Accessed on: 13/10/2018.

Colton, T.F. Alpert, P. (1998). Lack of Public Awareness of Biological Invasion by Plants. Natural Areas Journal, 18, 262266

Davenport, L. Brockelman, W.Y. Wright, P.C. Ruf, K. Rubio del Valle, F.B. (2002). Ecotourism Tools for Parks. In: Terborgh J, van Schaik C, Davenport L, Rao M, (Eds.) Making Parks Work. Washington D.C. Island Press, 279-306

De Ventura, L. Weissert, N. Tobias, R. Kopp, K. Jokela, J. (2016). Overland Transport of Recreational Boats as a Spreading Vector of Zebra Mussel Dreissena Polymorpha. Biological Invasions 18, 1451-1466

Department of Culture, Heritage and the Gaeltacht, [DCHG]. (2017). National Biodiversity Action Plan 2017-2021. Retrieved from: https://www.npws.ie/sites/ default/files/publications/ pdf/National\%20 Biodiversity\%20Action\%20Plan\%20Englis h.pdf. Accessed on: 17/09/2018.

Department of Primary Industries, [DPI]. (2013). New South Wales Biosecurity Strategy 2013 -2021. Retrieved from: https://www.dpi.nsw.gov.au/_data/assets /pdf_file/0005/ 467699/NSW-biosecuritystrategy-2013-2021.pdf. Accessed on: $31 / 05 / 2018$

Donohoe, H. Pennington-Gray, L. Omodior, O. (2015). Lyme disease: Current Issues, Implications, and Recommendations for Tourism Management. Tourism Management, 46, 408-418

European Commission, [EC]. (2014). Regulation (EU) No 1143/2014: The Prevention and Management of the Introduction and Spread of Invasive Alien Species (2014). Retrieved from:
https://eur-lex.europa.eu/legal-content/EN/ TXT/?qid $=1534951263404$ \&uri= CELEX: 32014R1143. Accessed on: 22/08/2018.

European Environmental Agency, [EEA]. (2012). The Impacts of Invasive Alien Species in Europe. European Environmental Agency Technical Report, 16, 1-118

Fáilte Ireland, (2016), Tourism Facts 2015. Retrieved from: http://www.failteireland.ie/ Failtelreland/media/WebsiteStructure/Doc uments/3_Research_Insights/3_General_ SurveysReports/Tourism-Facts-2015Preliminary.pdf?ext=.pdf. Accessed on: 11/04/2018.

Fáilte Ireland, (2018). Tourism Facts 2016, Revised March 2018. Retrieved from: http://www.failteireland.ie/Failtelreland/ media/WebsiteStructure/Documents/3_Re search_Insights/2_Regional_SurveysRep orts/Tourism-Facts-2016-Revised-March2018.pdf?ext=.pdf. Accessed on: 09/04/2018.

Findlater, A. Bogoch, I.I. (2018). Human Mobility and the Global Spread of Infectious Diseases: A Focus on Air Travel. Trends in Parasitology, 34, (9), $772-783$

Frith, J. (2012). The History of Plague - Part 1. The Three Great Pandemics. Journal of Military and Veterans' Health, 20(2), 11-15

Gaber, W. Goetsch, U. Diel, R. Doerr, H.W. Gottschalk, R. (2009). Screening for Infectious Diseases at International Airports: The Frankfurt Model. Aviation, Space, and Environmental Medicine, 80, 595-600

Great Britain Non-native Species Secretariat. (2015). Great Britain Invasive Non-native Species Strategy. Retrieved from: https://assets.publishing.service.gov.uk/ government/uploads/system/uploads/attac hment_data/file/455526/gb-non-nativespecies-strategy-pb14324.pdf. Accessed on: 04/09/2018.

Gunn, G.J. Heffernan, C. Hall, M. McLeod, A. Hovi, M. (2008). Measuring and Comparing Constraints to Improved Biosecurity amongst GB Farmers, Veterinarians and the Auxiliary Industries. Preventive Veterinary Medicine, 84, 310-323

Gushulak, B.D. MacPherson, D.W. (2004). Globalization of Infectious Diseases: The 
Impact of Migration. Clinical Infectious Diseases, 38, 1742-1748

Haas, W.H. Breuer, T. Pfaff,G. Schmitz, H. Köhler, P. Asper, M. Emmerich, P. Drosten, C. Gölnitz, U. Fleischer, K. Günther, S. (2003). Imported Lassa Fever in Germany: Surveillance and Management of Contact Persons. Clinical infectious diseases, 36(10), 1254-1258

Hall, C.M. (2005). Biosecurity and Wine Tourism. Tourism Management 26, 931938

Hall, C.M. (2006). Tourism, Disease and Global Environmental Change: The Fourth Transition? In Gössling, S. and Hall, C.M. (Eds) Tourism and Global Environmental Change: Ecological, Economic, Social and Political Interrelationships. Taylor \& Francis

Hall, C. M. (2011). Biosecurity, tourism and mobility: institutional arrangements for managing tourism-related biological invasions. Journal of Policy Research in Tourism, Leisure and Events, 3(3), 256280.

Hayes, J.N. (2005). Epidemics and Pandemics: Their Impacts on Human History. Santa Barbara, CA: ABC-CLIO.

Health Service Executive, [HSE]. (2007). National Pandemic Influenza Plan. Retrieved from: https://health.gov.ie/wpcontent/uploads/2014/03/nationalfluplan.p df. Accessed on: 08/10/2018.

Hong Kong Trade Development Council, [HKTDC]. (2003). Economic Impact of SARS on Chinese Economy. Retrieved from: $\quad$ http://info.hktdc.com/alert/cbae0306sp-4.htm. Accessed on: 16/10/2018.

Hulme, P.E. (2009). Trade, Transport and Trouble: Managing Invasive Species Pathways in an Era of Globalization. Journal of Applied Ecology, 46, 10-18

Hulme, P.E. Bacher, S. Kenis, M. Klotz, S. Kühn, I. Minchin, D. Nentwig, W. Olenin, S Panov, V. Pergl, J. Pyšek, P. Roques, A. Sol, D. Solarz, W. Vilà, M. (2008). Grasping at the Routes of Biological Invasions: A Framework to Better Integrate Pathways into Policy. Journal of Applied Ecology, 45, 403-414

Inland Fisheries Ireland, [IFI]. (2011). Biosecurity Guidelines. Retrieved from: https://www.
fisheriesireland.ie/Research/invasivespecies.html. Accessed on: 21/09/2018.

Inland Fisheries Ireland, [IFI]. (2012). Inland Fisheries Ireland Respond to Invasive Species Alert on the Grand Canal, Press release June 1st, 2012. Retrieved from: https://www. fisheriesireland.ie/Pressreleases/inland-fisheries-ireland-respondto-invasive-species-alert-on-the-grandcanal.html. Accessed on: 02/10/2018.

Inland Fisheries Ireland, [IFI]. (2013). CAISIE [Control of Aquatic Invasive Species and Restoration of Natural Communities in Ireland] After Life Communication Plan. Retrieved from: https://www.fisheriesireland.ie/documents/ 371-caisie-after-life-communication-plan-

1/file.html. Accessed on: 25/09/2018.

Inland Fisheries Ireland, [IFI]. (2015). Post-Trial Dredge Report, Hot Water Section, Lanesborough. Retrieved from: https://www.fisheriesireland.ie/documents/ 533-post-trial-dredge-report-hot-watersection-lanesborough/file.html. Accessed on: 19/09/2018.

International Air Transport Association, [IATA]. (2017) IATA Annual Review 2017, IATA

Jauni, M. Gripenberg, S. Ramula, S. (2014). Non-Native Plant Species Benefit from Disturbance: A Meta-Analysis. Oikos, 124, 122-129

Jen Shih, T. Wijaya, R. Brossard, D. (2008) Media Coverage of Public Health Epidemics: Linking Framing and Issue Attention Cycle Toward an Integrated Theory of Print News Coverage of Epidemics. Mass Communication and Society, 11(2), 141-160

Johnson, L.E. Ricciardi, A. Carlton, J.T. (2001). Overland Dispersal of Aquatic Invasive Species: A Risk Assessment of Transient Recreational Boating. Ecology Application, 11, 1789-1799.

Kelly, J. Tosh, D. Dale, K. Jackson, A. (2013) The Economic Cost of Invasive and NonNative Species in Ireland and Northern Ireland. A Report Prepared for the Northern Ireland Environment Agency and National Parks and Wildlife Service as Part of Invasive Species Ireland. Retrieved from: https://invasivespeciesire land.com/wp-content/uploads/2010/07/ Economic_Impact_Assessment_ 
FINAL 280313.pdf. Accessed on: $01 / 11 / 2018$.

Kemp, C. van Riper, C.J. BouFajreldin, L. Stewart, W.P. Scheunemann, J. van den Born, R.J.G. (2017). Connecting HumanNature Relationships to Environmental Behaviours that Minimize the Spread of Aquatic Invasive Species. Biological Invasions, 19, 2059-2074

Kueffer, C. (2010). Transdisciplinary Research is needed to Predict Plant Invasion in an Era of Global Change. Trends in Ecology \& Evolution, 25, 619-620

Layton, D.S. Choudhary, A. Bean, A.G.D. (2017). Breaking the Chain of Zoonoses through Biosecurity in Livestock. Vaccine, 35, (44), 5967-5973

Leung, D. Law, R. van Hoof, H. Buhalis, D. (2013). Social Media in Tourism and Hospitality: A Literature Review. Journal of Travel \& Tourism Marketing, 30, 3-22

$\mathrm{Li}, \mathrm{X}$. Wang, Y.C. (2011). China in the Eyes of Western Travellers as Represented in Travel Blogs. Journal of Travel \& Tourism Marketing, 28(7), 689-719

McAleer, M. Huang, B.W. Kuo, H.I. Chen, C.C. Chang, C.L. (2010). An Econometric Analysis of SARS and Avian Flu on International Tourist Arrivals to Asia. Environmental Modelling \& Software, 1, 100-106

Media and Communications Working Group, [MCWG]. (2017). The Invasive Non-native Species Media and Communications Plan for Great Britain. Retrieved from: www.nonnativespecies.org/downloadDocu ment.cfm?id=1587. Accessed on: 04/09/2018.

Miles, M.B. Huberman, A.M. (1994). Qualitative Data Analysis: An Expanded Sourcebook (2nd ed.), Thousand Oaks, CA: Sage.

Minchin, D. Maguire, C. Rosell, R. (2003). The Zebra Mussel (Dreissena Polymorpha Pallas) Invades Ireland: Human Mediated Vectors and the Potential for Rapid Intranational Dispersal. Biology and Environment: Proceedings of the Royal Irish Academy, 103B(1), 23-30.

Moore, D.W. (2004). SARS: Preventative Plans Key to Managing Health Risk in a Construction Environment in China, Professional Safety, 18-24
National Biodiversity Data Centre, [NBDC]. (2018), Species Designation Browser, Invasive species. Retrieved from: http://maps.biodiversityireland.ie/\#/Design ation/1/Designation Group. Accessed on: 07/02/2018.

Nerlich, B. Koteyko, N. (2012). Crying Wolf? Biosecurity and Metacommunication in the Context of the 2009 Swine Flu Pandemic. Health \&Place, 18, 710-717

Newsome, D. Smith, A. Moore, S.A. (2008). Horse Riding in Protected Areas: A Critical Review and Implications for Research and Management. Current Issues in Tourism, 11, 144-166.

Nöremark, M. Sternberg Lewerin, S. Ernholm, L. Frössling, J. (2016). Swedish Farmers' Opinions about Biosecurity and their Intention to make Professionals use Clean Protective Clothing when Entering the Stable. Frontiers in Veterinary Science, 3, 46

Novoa, A. Shackleton, R. Canavan, S. Cybèle, C. Davies, S.J. Dehnen-Schmutz, K. Fried, J. Gaertner, M. Geerts, S. Griffiths, C.L. Kaplan, H. Kumschick, S. Le Maitre, D.C. Measey, G.J. Nunes, A.L. Richardson, D.M. Robinson, T.B. Touza, J. Wilson, J.R.U. (2018). A Framework for Engaging Stakeholders on the Management of Alien Species. Journal of Environmental Management, 205, 286-297

Novoa, A. Dehnen-Schmutz, K. Fried, J. Vimercati, G. (2017). Does Public Awareness Increase Support for Invasive Species Management? Promising Evidence across Taxa and Landscape Types. Biological Invasions, 19, 3691-3705

O'Connor, C.M Haydon, D.T. Kao, R.R. (2012). An Ecological and Comparative Perspective on the Control of Bovine Tuberculosis in Great Britain and the Republic of Ireland. Preventive Veterinary Medicine, 104, 185-197

O'Flynn, C. Kelly, J. Lysaght, L. (2014). Ireland's Invasive and Non-Native Species - Trends in Introductions. National Biodiversity Data Centre Series No. 2. Ireland. Retrieved from: http://www.biodiversityireland.ie/wordpres s/wp-content/uploads/Trends-Report2013.pdf. Accessed on: 13/11/2018. 
O'Reilly, P.J. O'Connor, M. Harrington, A. Gaynor, S. Clery, D. (2003). Foot and Mouth Disease in Ireland; History, Diagnosis, Eradication and Serosurveillance. Retrieved from: http://www.fao.org/ag/againfo/commission s/docs/research_group/izmir/app03.pdf. Accessed on: 25/09/2018.

O'Toole, R. Matthews, A. Mulvey, M. (2002). Impact of the 2001 foot and mouth outbreak on the Irish economy. The IMAGE project working paper. Trinity College, Dublin. 1-27

Palmer, S. Fozdar, F. Sully, M (2009). The Effect of Trust on West Australian Farmers' Responses to Infectious Livestock Diseases. Sociologia Ruralis, 49, 360-374

Pickering, C.M. Bear, R. Hill, W. (2007). Indirect Impacts of Nature Based Tourism and Recreation: The Association between Infrastructure and the Diversity of Exotic Plants in Kosciuszko National Park, Australia. Journal of Ecotourism, 6, 146157

Pickering, C.M. Hill, W. Newsome, D. Leung, Y.F. (2010). Comparing Hiking, Mountain Biking and Horse Riding Impacts on Vegetation and Soils in Australia and the United States of America. Journal of Environmental Management, 91, 551-562

Powell, D. Leiss, W. (1997). Mad Cows and Mother's Milk: The Perils of Poor Risk Communication. Montreal: Mcgill-Queens University Press.

Pyšek, P. Richardson, D.M. (2010). Invasive Species, Environmental Change, Management, and Health. The Annual Review of Environment and Resources, $35,25-55$

Rassy, D. Smith, R.D. (2013). The Economic Impact of H1N1 on Mexico's Tourist and Pork Sectors. Health Economics, 22, (7), 824-834

Reis, C.S. Marchante, H. Freitas, H. Marchante, E. (2011). Public Perception of Invasive Plant Species: Assessing the Impact of Workshop Activities to Promote Young Students Awareness. International Journal of Science Education, 35, 690712

Rothlisberger, J.D. Chadderton, W.L. McNulty, J. Lodge, D.M. (2010). Aquatic Invasive
Species Transport Via Trailered Boats: What is Being Moved, Who is Moving it, and What Can Be Done. Fisheries, 35, 121-132.

Sayers, R.G. Sayers, G.P. Mee, J.F. Good, M. Bermingham, M.L. Grant, J. Dillon, P.G. (2013). Implementing Biosecurity Measures on Dairy Farms in Ireland. Veterinary Ireland Journal, 197, 259-267

Schneider, D.W. Ellis, C.D. Cummings, K.S. (1998). A Transportation Model Assessment of the Risk to Native Mussel Communities from Zebra Mussel Spread. Conservation Biology, 12, 788-800

Shackleton, C.M. Shackleton, R.T. (2016). Knowledge, Perceptions and Willingness to Control Designated Invasive Tree Species in Urban Household Gardens in South Africa. Biological Invasions, 18, 1599-1609

Shih, T. Wijaya, R. Brossard, R. (2008). Media Coverage of Public Health Epidemics: Linking Framing and Issue Attention. Cycle toward an Integrated Theory of Print News Coverage of Epidemics. Mass Communication and Society, 11, 141-160

Smith, R.D. (2006). Responding to Global Infectious Disease Outbreaks: Lessons from SARS on the Role of Risk Perception, Communication and Management. Social Science \& Medicine, 63, 3113-3123

Stokes, K. O'Neill, K. McDonald, R.A. (2004). Invasive Species in Ireland. Unpublished Report to Environment \& Heritage Service and National Parks \& Wildlife Service. Quercus, Queens University Belfast, Belfast. Retrieved from: https://www.npws.ie/sites/default/ files/publications/pdf/Stokes_et_al_2004_I AS_Ireland.pdf. Accessed on: 10/11/2018.

Thevenot, G. (2007). Blogging as a Social Media. Tourism and Hospitality Review, 7(3-4), 287-289

Tobin, P.C. Van Stappen, J. Blackburn, L.M. (2010). Human Visitation Rates to the Apostle Islands National Lakeshore and the Introduction of the Non-Native Species. Lymantria dispar (L.). Journal of Environmental Management, 91, 19911996

Tourism Ireland. (2015). Overseas Tourism Performance. Retrieved from: 
https://www.tourismireland.com/Tourismlr eland/media/Tourism-

Ireland/Research/Facts-and-Figures-

2015.pdf?ext=.pdf. Accessed on: 18/09/2018.

Tourism Ireland. (2016). 2016 Facts \& Figures. Retrieved from: https://www.tourism ireland.com/Tourismlreland/media/Touris mlreland/Press\%20Releases/Press\%20R eleases\%202017/Facts-and-Figures2016.pdf?ext=.pdf. Accessed on: 18/09/2018.

Tverijonaite, E. Ólafsdóttir, R. Thorsteinsson, T. (2018). Accessibility of Protected Areas and Visitor Behaviour: A Case Study from Iceland. Journal of Outdoor Recreation and Tourism, 24, 1-10

U.S. Fish and Wildlife Service. (2015). Protect Your Waters and Stop Aquatic Hitchhikers. Retrieved from: http://www.stopaquatichitchhikers.org. Accessed on 19/09/2018.

United Nations World Tourism Organisation, [UNWTO]. (2018). 2017 International Tourism Results: The Highest in Seven Years. Retrieved from: http://media.unwto.org/pressrelease/2018-01-15/2017-internationaltourism-results-highest-seven-years. Accessed on 06/02/2018.

Wald, D.M. Nelson, K.A. Gawel, A.M. Rogers, H.S. (2018). The Role of Trust in Public Attitudes towards Invasive Species Management on Guam: A Case Study. Journal of Environmental Management, 229, 133-144

Wilder-Smith, A. Paton, N.I. Goh, K.T. (2003). Short Communication: Low Risk of Transmission of Severe Acute Respiratory Syndrome on Airplanes: The Singapore Experience. Tropical Medicine and International Health, 8(11), 1035-1037

Williams, F. Eschen, R. Harris, A. Djeddour, D. Pratt, C. Shaw, R. S. Varia, S. Lamontagne-Godwin, J. Thomas, S. E. Murphy, S. T. (2010). The Economic Cost of Invasive Non-Native Species on Great Britain, Wallingford: CABI for the Scottish
Government, Department for Environment Food and Rural Affairs UK Government, and Department for Economy and Transport Welsh Assembly Government. Retrieved from: www.nonnativespecies. org/downloadDocument.cfm?id=487. (Accessed on 12/09/2018).

World Health Organisation, [WHO]. (2005). Global Influenza Preparedness Plan: The Role of WHO and Recommendations for National Measures Before and During Pandemics. WHO/CDS/CSR/GIP/2005.5. Geneva: Global Influenza Programme; 2005. Retrieved from: http://www.who.int/csr/resources/publicati ons/influenza/WHO_CDS_CSR_GIP_200 5_5.pdf. Accessed on: 08/10/2018.

World Health Organisation, [WHO]. (2008). World Health Organisation Outbreak Communication Planning Guide. Retrieved from:

http://www.who.int/ihr/elibrary/

WHOOutbreakCommsPlanngGuide.pdf. Accessed on: 24/09/2018.

World Health Organisation, [WHO]. (2009). Pandemic Influenza Preparedness and Response: A WHO Guidance Document. Retrieved from: http://apps.who.int/iris/bitstream/handle /10665/44123/9789241547680_eng.pdf;js essionid=B74F5CDC77B47E80DC90213 B95B98A9E? sequence $=1$. Accessed on: 24/09/2018.

World Health Organisation, [WHO]. (2010). Biosecurity: An Integrated Approach to Manage Risk to Human, Animal and Plant Life and Health. Retrieved from: http://www.who.

int/foodsafety/fs_management/No_01_Bio security_Mar10_en.pdf. Accessed on: 17/09/2018.

World Travel \& Trade Council, [WTTC]. (2018). Travel \& Tourism Economic Impact 2018 Ireland. Retrieved from: https://www.wttc. org/-/media/files/reports/economic-impactresearch/countries-2018/ireland2018.pdf. Accessed on: 18/10/2018. 